\title{
Abbreviations
}

\begin{tabular}{|c|c|}
\hline AGN & Archivo General de la Nación, Mexico City \\
\hline ANS & $\begin{array}{l}\text { The Art of Nahuatl Speech: The Bancroft Dialogues, ed. } \\
\text { Karttunen and Lockhart }\end{array}$ \\
\hline $\mathrm{AZ}$ & Aztekischer Zensus, ed. Hinz et al. \\
\hline $\mathrm{BC}$ & Beyond the Codices, by Anderson, Berdan, and Lockhart \\
\hline CA & Codex Aubin (Historia de la nación mexicana, ed. Dibble) \\
\hline CAN & Colección Antigua in MNAH AH \\
\hline $\mathrm{CDC}$ & $\begin{array}{l}\text { Colección de documentos sobre Coyoacán, ed. Carrasco and } \\
\text { Monjarás-Ruiz }\end{array}$ \\
\hline CFP & $\begin{array}{l}\text { "De la Cruz family papers," Tepemaxalco (Calimaya), } \\
\text { MNAH AH, GO I } 86\end{array}$ \\
\hline $\mathrm{CH}$ & $\begin{array}{l}\text { Die Relationen Chimalpabin's zur Geschichte Mexico's, ed. } \\
\text { Zimmermann }\end{array}$ \\
\hline FC & $\begin{array}{l}\text { Florentine Codex: General History of the Things of New } \\
\text { Spain, by Sahagun, tr. Anderson and Dibble }\end{array}$ \\
\hline GO & Gómez de Orozco Collection in MNAH AH \\
\hline $\mathrm{HJ}$ & Hospital de Jesús, a section in AGN \\
\hline HTC & $\begin{array}{l}\text { Historia tolteca-chichimeca, ed. Kirchhoff, Güemes, and } \\
\text { Reyes García }\end{array}$ \\
\hline MNAH AH & $\begin{array}{l}\text { Archivo Histórico of the Museo Nacional de Antropología e } \\
\text { Historia, Mexico City }\end{array}$ \\
\hline Molina & $\begin{array}{l}\text { Vocabulario castellano y mexicano y mexicano y castellano, } \\
\text { by fray Alonso de Molina (I } 57 \mathrm{I}) \text {, } 1970 \text { edition }\end{array}$ \\
\hline NAC & Newberry Library, Ayer Collection \\
\hline & Nabuatl in the Middle Years, by Karttunen and Lockhart \\
\hline$N \& S$ & Nabuas and Spaniards, by Lockhart \\
\hline RA & $\begin{array}{l}\text { Treatise on the Heathen Superstitions, by Ruiz de Alarcón, } \\
\text { ed. Andrews and Hassig }\end{array}$ \\
\hline & The Tlaxcalan Actas, by Lockhart, Berdan, and \\
\hline
\end{tabular}


TC

TCB

TN

UCLA TC

$\mathrm{ZM}$
Testaments of Culbuacan, ed. Cline and León-Portilla Tula Cofradía Book, in Lilly Library, Indiana University, section Latin American Mss.-Mexico

Teatro nábuatl, by Horcasitas

UCLA Research Library Special Collections, Tulancingo

Collection

The annals of don Juan Buenaventura Zapata y Mendoza,

Bibliothèque Nationale, Paris, Mexican ms. 2 I 2 


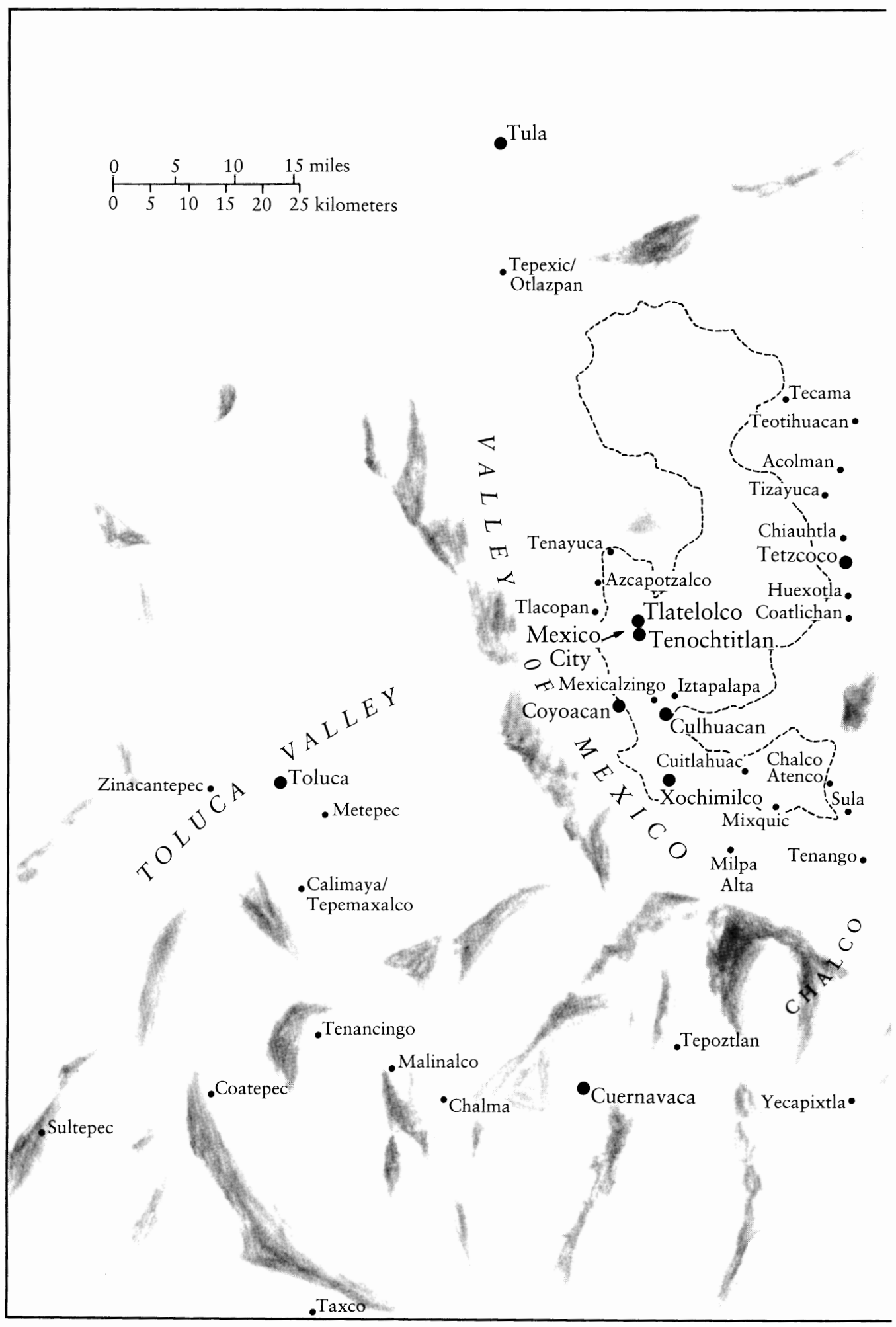




\section{-Acatlan Acaxochitlan}

-Tulancingo

-Otumba

.Tepetlaoztoc

T E P E T I C P A C

\section{Q U I A H U I Z T L A N • T I ÇA T L A •Huamantla Tlaxcala}

O C O T E L O L C O

-Tlalmanalco

Amaquemecan

Ayapango

(Amecameca)

-Soyatzingo

-Atlauhtlan

- Chimalhuacan

petlixpan

- Huejotzingo

-Calpan

Cholula

-Puebla

- Cuauhtinchan

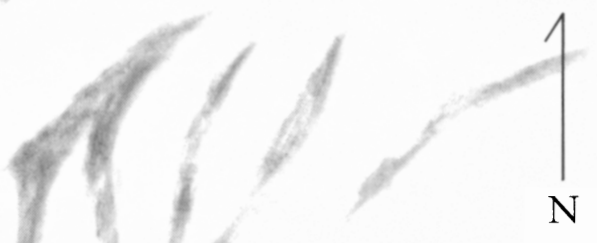





\section{The Nahuas}

After the Conquest 
